Jap. J. M. Sc. \& Biol., 10, 455-459, 1957

\title{
ANTITUMOR EFFECT OF 2-SUBSTITUTED BENZIMIDAZOLE ON SOLID TYPE OF EHRLICH ASCITES TUMOR ${ }^{1)}$
}

\author{
Tomoyoshi KOMAI ${ }^{2}$, Hiroko HIGURASHI ${ }^{3)}$, MIHoko ABE ${ }^{4}$ AND \\ DEN-ICHI MIZUNO \\ Department of Chemistry, National Institute of Health, Tokyo ${ }^{6)}$ \\ (Received: November 2nd, 1957)
}

Tamm et al., Folkers et al. (1951, 1953) examined extensively an antiinfluenza virus action of 2 -substituted benzimidazole derivatives and reported a marked effect of isopropyl and n-butyl derivatives among 2-alkylsubstituted benzimidazole. They did not report the effect of the higher alkyl substitution. They considered at first these substances as an antimetabolite against vitamin $\mathrm{B}_{12}(\mathrm{~N}-\alpha$-D-ribofuranoside) and finally reported that 5,6-dichloro- $\mathrm{N}$ - $\beta$-ribofuranoside was the most effective (Tamm et al., 1954, 1956). Allfrey et al. (1957) described that this substance was an antimetabolite of RNA inhibiting a labelled amino acid incorporation into the nucleus of calf thymus tissue.

Antitumor effect of benzimidazole is not so marked (Skipper et al., 1950; Biesele et al., 1951; Mantegazza et al., 1951; Flint et al., 1953). However, we intended to synthesize the derivatives of benzimidazole which can possibly be a purine antimetabolite. Therefore, we did not consider 5,6- but 4,6-substituted derivatives and $\mathrm{N}-\beta$-riboside instead of $\alpha$-riboside aiming at the adenosine and guanosine which contain $\mathrm{N}$ - $\beta$-riboside.

The present paper deals with the results testing the antitumor effect of 2-substituted benzimidazole and of its 6-nitro derivatives newly synthesized by us. Nucleosides analogues are now being synthesized.

\section{MATERIALS AND MethodS}

Synthesis: A slight excess of fatty acid which has a longer chain by one methylene than the side chain to be attached at position 2 was added to 0 -phenylenediamine and boiled for 1-2 hours in the presence (less than four charbons) of catalytic amount of hydrochloric acid. The reaction mixture was cooled and neutralized by aq. ammonia to give a precipitate of 2 -substituted benzimidazole. Recrystallized from water or alcohol. The hydrochloride was obtained by recrystallization of the base from dilute hydrochloric acid.

The nitration was done following the conventional method by a mixture of sulfuric

\footnotetext{
${ }^{1}$ The same article in Japanese has already been published in The Journal of the Pharmaceutical Society of Japan, 77, (1957).

2)駒井知好・3) 日暮弘子・4)阿部美穂子・5) 水野伝一，6)国立予防衛生研究所化学部
} 
acid and nitric acid at $10^{\circ} \mathrm{C}$. The reaction mixture was poured into ice water to isolate crystalline precipitate. The basic 6-nitro-2-alkyl benzimidazole was obtained when the crystal was dissolved in hot water or alcohol and neutralized by alkaline solution. The hydrochloride was obtained by recrystallization of the base from dilute hydrochloric acid or alcoholic hydrochloric acid.

Table 1. Analytical data of new compounds in 2-substituted benzimidazole series

\begin{tabular}{|c|c|c|c|c|c|c|c|c|c|}
\hline \multirow{2}{*}{ Formula } & & \multirow{2}{*}{$\mathrm{mp}$} & \multicolumn{2}{|c|}{$\mathrm{C}$} & \multicolumn{2}{|c|}{$\mathrm{H}$} & \multicolumn{2}{|c|}{$\mathrm{N}$} & \multirow{2}{*}{$\begin{array}{l}\text { Yield } \\
\%\end{array}$} \\
\hline & & & Calc. 1 & Found $\mathrm{C}$ & Calc. $F$ & Found & Calc. $\mathrm{I}$ & Found & \\
\hline \multicolumn{10}{|l|}{-R: } \\
\hline $\mathrm{C}_{2} \mathrm{H}_{5}$ & $\mathrm{C}_{9} \mathrm{H}_{9} \mathrm{O}_{2} \mathrm{~N}_{3}$ & $178^{\circ}$ & 56.55 & 56.01 & 4.71 & 14.76 & 21.99 & 922.52 & 52 \\
\hline $\mathrm{C}_{3} \mathrm{H}_{7}$ & $\mathrm{C}_{10} \mathrm{H}_{11} \mathrm{O}_{2} \mathrm{~N}_{3}$ & $159-61^{\circ}$ & 58.54 & 58.69 & 5.37 & 75.44 & 20.49 & 920.62 & 78 \\
\hline $\mathrm{C}_{4} \mathrm{H}_{9} *$ & $\mathrm{C}_{11} \mathrm{H}_{14} \mathrm{O}_{2} \mathrm{~N}_{3} \mathrm{Cl}$ & $137^{\circ}$ & 50.86 & 51.60 & 5.40 & 5.61 & 16.18 & $\begin{array}{ll}8 & 16.79\end{array}$ & 28 \\
\hline $\mathrm{C}_{5} \mathrm{H}_{11} *$ & $\mathrm{C}_{12} \mathrm{H}_{16} \mathrm{O}_{2} \mathrm{~N}_{3} \mathrm{Cl}$ & $213-5^{\circ}$ & 53.44 & 52.73 & 5.95 & 5.87 & 15.58 & $\begin{array}{ll}8 & 15.68\end{array}$ & 35 \\
\hline $\mathrm{C}_{6} \mathrm{H}_{13} *$ & $\mathrm{C}_{13} \mathrm{H}_{18} \mathrm{O}_{2} \mathrm{~N}_{3} \mathrm{Cl}$ & $220-2^{\circ}$ & 55.03 & 54.83 & 5.79 & 96.20 & 14.81 & 114.45 & 25 \\
\hline $\mathrm{C}_{7} \mathrm{H}_{15} *$ & $\mathrm{C}_{14} \mathrm{H}_{20} \mathrm{O}_{2} \mathrm{~N}_{3} \mathrm{Cl}$ & $195-7^{\circ}$ & 56.47 & 56.51 & 6.73 & 36.60 & 14.12 & 214.15 & 20 \\
\hline $\mathrm{C}_{9} \mathrm{H}_{19} *$ & $\mathrm{C}_{16} \mathrm{H}_{24} \mathrm{O}_{2} \mathrm{~N}_{3} \mathrm{Cl}$ & $211-3^{\circ}$ & 58.98 & 58.63 & 7.38 & $\begin{array}{ll}8 & 7.38\end{array}$ & 12.92 & 213.85 & 21 \\
\hline $\mathrm{C}_{11} \mathrm{H}_{23} *$ & $\mathrm{C}_{18} \mathrm{H}_{28} \mathrm{O}_{2} \mathrm{~N}_{3} \mathrm{Cl}$ & $\begin{array}{r}205-8^{\circ} \\
\text { decomp.) }\end{array}$ & 61.13 & 60.90 & 7.92 & 8.43 & 11.87 & $7 \quad 11.40$ & 22 \\
\hline $\mathrm{C}_{13} \mathrm{H}_{27} *$ & $\mathrm{C}_{20} \mathrm{H}_{32} \mathrm{O}_{2} \mathrm{~N}_{3} \mathrm{Cl}$ & $\begin{array}{r}203-5^{\circ} \\
\text { decomp.) }\end{array}$ & 62.91 & 63.47 & 8.39 & 98.35 & 11.01 & 110.86 & 30 \\
\hline $\mathrm{C}_{15} \mathrm{H}_{31}$ * & $\mathrm{C}_{22} \mathrm{H}_{36} \mathrm{O}_{2} \mathrm{~N}_{3} \mathrm{Cl}$ & $\begin{array}{l}\text { 195-200 } \\
\text { decomp.) }\end{array}$ & 64.47 & 64.35 & 8.79 & 98.86 & 10.26 & $\begin{array}{ll}6 & 10.34\end{array}$ & 25 \\
\hline $\mathrm{C}_{6} \mathrm{H}_{4} \mathrm{NO}_{2}$ & $\mathrm{C}_{13} \mathrm{H}_{8} \mathrm{O}_{4} \mathrm{~N}_{4}$ & $\begin{array}{r}330-5^{\circ} \\
\text { decomp.) }\end{array}$ & 55.00 & 54.54 & 2.82 & 23.25 & 19.72 & $\begin{array}{ll}2 & 20.17\end{array}$ & 17 \\
\hline $\mathrm{CH}_{2} \mathrm{C}_{6} \mathrm{H}_{4} \mathrm{NO}_{2} * *$ & $\mathrm{C}_{14} \mathrm{H}_{14} \mathrm{O}_{6} \mathrm{~N}_{4}$ & $\begin{array}{c}241^{\circ} \\
\text { decomp.) }\end{array}$ & 50.30 & 51.10 & 4.19 & 3.70 & 16.75 & $5 \quad 17.50$ & 8 \\
\hline
\end{tabular}

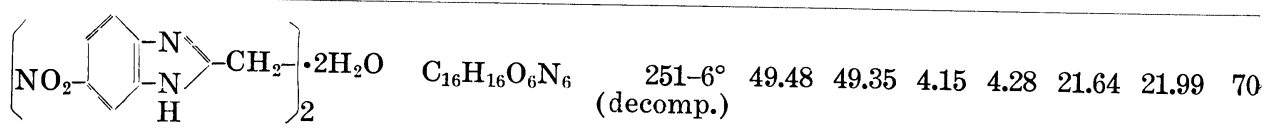

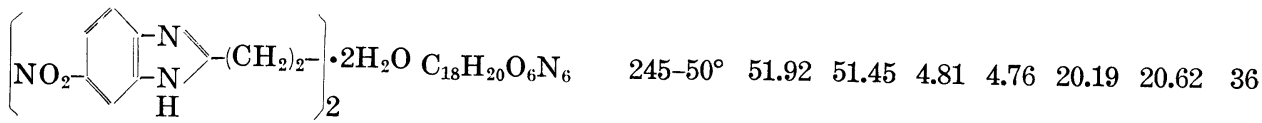

* These are hydrochloride salts.

** It contains two moles of crystal water.

Screening for antitumor effect: The neoplasm employed was Ehrlich ascites tumor maintained in our laboratory being transplanted intraperitoneally every week. dd mice 15-20 g, received a diet of Oriental pellets and water. The screening followed essentially Sugiura's method (Sugiura, 1955). The Ehrlich ascites tumor cells obtained 4-7 days after the intraperitoneal implantation were made to $10,000,000$ cells/ cc and $0.2 \mathrm{cc}$ of this suspension ( $c a .2$ million cells) was transplanted subcutaneously to dd mice. The body weight was weighed every day and no weight decrease of the 
animals was observed throughout the experimental periods. Drug suspension was made in saline or in $0.5 \%$ CMC solution. Therapy was initiated 24 hours after transplantation and continued once a day for seven days except Sunday ( $1.25 \mathrm{mg} / \mathrm{mouse})$. The mice were killed by etherization 11-12 days after tumor implantation. The tumors were removed and the wet weights were determined to the nearest milligram. Results were interpreted following the expression of Sloan-Kettering method:

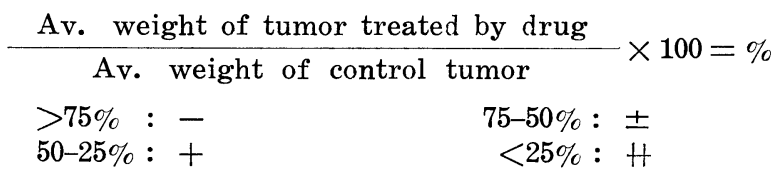

\section{RESULTS AND Discussion}

Table 2 showed the results of 2-alkyl-substituted benzimidazole. 2-Propyl compound showed the activity of $73 \%( \pm)$, while its 6-nitro compound increases the activity up to $48 \%(+)$. The same increase of activity was shown in case of 2-amyl (88\%) and its 6-nitro compound (62\%). A slight activity was seen in $\mathrm{C}_{11}$ and its longer chain compounds but their nitro compounds did not show any increase of activity.

Table 3 showed the results of 2-phenylalkyl and biscompounds as well as their nitro compounds. In these groups no marked activity was found except that slight effect was found in a bis-2-substituted nitro compound.

Table 2. Antitumor activity of 2-alkyl-substituted benzimidazole

\begin{tabular}{|c|c|c|c|c|c|c|c|c|}
\hline & $\begin{array}{c}\text { No. } \\
\text { of } \\
\text { Exp. }\end{array}$ & $\begin{array}{l}\text { Average } \\
\text { increase } \\
\text { of body } \\
\text { weight }\end{array}$ & $\begin{array}{l}\text { Inhibition } \\
\text { percen- } \\
\text { tage }\end{array}$ & & $\begin{array}{c}\text { No. } \\
\text { of } \\
\text { Exp. }\end{array}$ & $\begin{array}{l}\text { Average } \\
\text { increase } \\
\text { of body } \\
\text { weight }\end{array}$ & $\begin{array}{l}\text { Inhibition } \\
\text { percen- } \\
\text { tage }\end{array}$ & \\
\hline \multicolumn{9}{|l|}{$-\mathrm{R}:$} \\
\hline$-\mathrm{H}$ & 6 & 2.1 & $88 \pm 13.2$ & - & 5 & 1.6 & $99 \pm 11.7$ & - \\
\hline$-\mathrm{CH}_{3}$ & 6 & 2.5 & $86 \pm 11.4$ & - & 5 & 2.5 & $91 \pm 14.2$ & - \\
\hline$-\mathrm{C}_{2} \mathrm{H}_{5}$ & 7 & 2.4 & $95 \pm 12.2$ & - & 2 & 3.6 & $96 \pm 23.7$ & - \\
\hline$-\mathrm{C}_{3} \mathrm{H}_{7}$ & 8 & 2.6 & $73 \pm 7.0$ & \pm & 8 & 1.9 & $48 \pm 20.4$ & + \\
\hline$-\mathrm{C}_{3} \mathrm{H}_{7}$ iso & 4 & 2.1 & $109 \pm 24.2$ & - & & & & \\
\hline$-\mathrm{C}_{4} \mathrm{H}_{9}$ & 6 & 2.5 & $92 \pm 12.4$ & - & 6 & 2.2 & $94 \pm 22.2$ & - \\
\hline$-\mathrm{C}_{4} \mathrm{H}_{9}$ iso & 6 & 2.3 & $96 \pm 18.3$ & - & & & & \\
\hline$-\mathrm{C}_{5} \mathrm{H}_{11}$ & 6 & 1.2 & $88 \pm 10.9$ & - & 4 & 2.0 & $62 \pm 6.0$ & \pm \\
\hline$-\mathrm{C}_{6} \mathrm{H}_{13}$ & 6 & 2.9 & $105 \pm 16.6$ & - & 4 & 2.3 & $95 \pm 33.0$ & - \\
\hline$-\mathrm{C}_{7} \mathrm{H}_{15}$ & 5 & 3.7 & $113 \pm 16.3$ & - & 4 & 3.2 & $103 \pm 9.5$ & - \\
\hline$-\mathrm{C}_{9} \mathrm{H}_{19}$ & 4 & 3.4 & $125 \pm 35.0$ & - & 3 & 1.4 & $114 \pm 6.0$ & - \\
\hline$-\mathrm{C}_{11} \mathrm{H}_{23}$ & 2 & 3.9 & $75 \pm 13.7$ & - & 1 & 2.8 & $104 \pm 7.8$ & - \\
\hline$-\mathrm{C}_{13} \mathrm{H}_{27}$ & 2 & 2.8 & $84 \pm 7.0$ & - & 1 & 3.1 & $139 \pm 8.9$ & - \\
\hline$-\mathrm{C}_{15} \mathrm{H}_{31}$ & 1 & 2.3 & $88 \pm 14.0$ & - & 2 & 2.3 & $66 \pm 15.0$ & - \\
\hline
\end{tabular}


Table 3. Antitumor activity of various 2-substituted benzimidazole

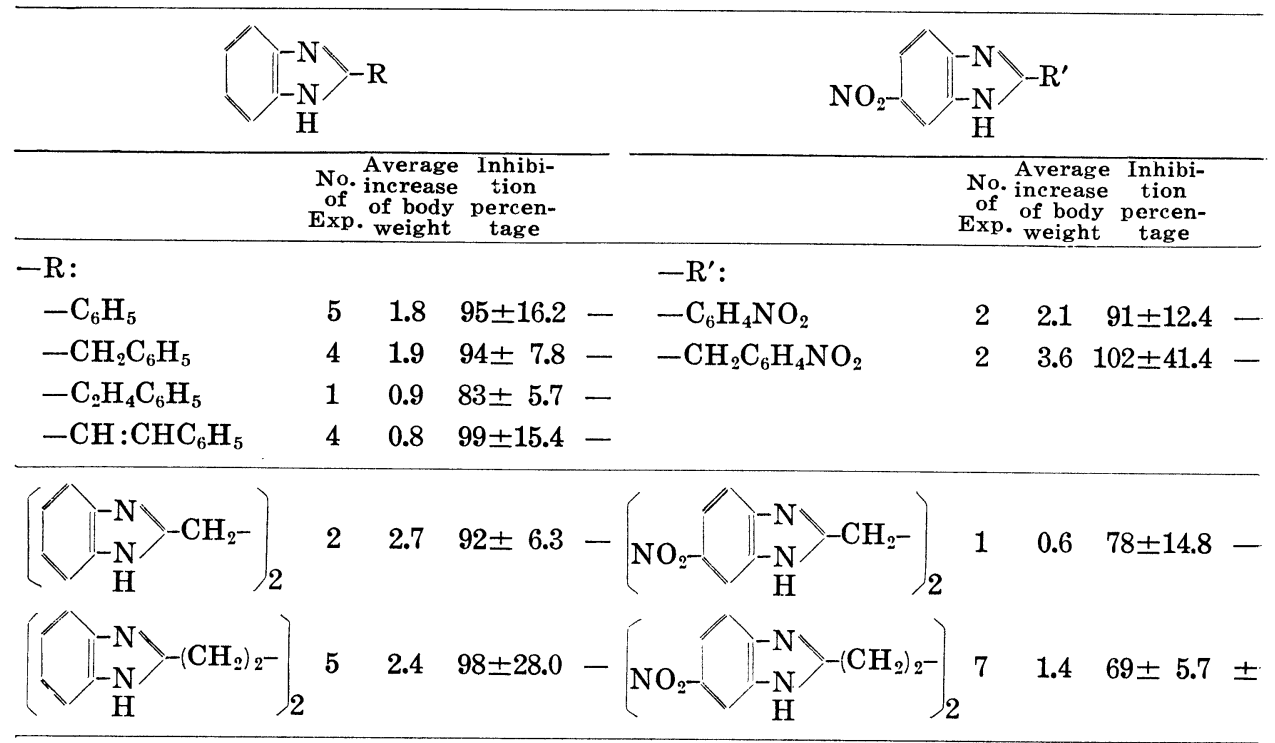

The screening was carried out by Sugiura's method. Subcutaneous implantation of Ehrlich ascites tumors was done into the right inguinal region of mouse. The tumor weight was compared with control giving the inhibition percentage and,+ \pm , -. Details were given in the text. Each group comprises 10 mice, i.e., 8 in No. of Exp. means 80 mice in 8 times of experiments.

In view of these results obtained above our next step is to synthesize a series of compounds having a propyl group at position 2 , ribosyl at 1 , and some heterogeneous group in benzene ring aiming finally at antimetabolites of adenosine or guanosine. The study is now in progress.

\section{SUMMARY}

1. Thirty-six compounds of 2-substituted benzimidazole derivatives were synthesized. Analytical data of fourteen new compounds were described.

2. These thirty-six compounds were screened for antitumor effect by Sloan-Kettering method using Ehrlich ascites tumor subcutaneously.

3. A slight effect was found in 2-propyl-benzimidazole and its 6-nitro compound showed more increased activity.

The authors are indebted to Dr. T. Yamamoto, Institute for Infectious Diseases, and Dr. T. Takeuchi, Department of Antibiotics, National Institute of Health, for their helpful advices in carrying out this work.

\section{REFERENCES}

Allfrey, V. G., Mirsky, A. E. and Osawa, S. (1957): Protein synthesis in cell nuclei. J. Gen. Physiol., 40, 451-490.

Biesele, J. J., Berger, R. E., Wilson, A. Y., Hitching, G. H. and Elion, G. B. (1951) : 
Studies on 2,6-diaminopurine and related substances in cultures of embryonic and sarcomatous rodent tissues. Cancer, 4, 186-197.

Flint, T. J., Hirschberg, E. and Murray, R. (1953) : Comparative effect of chemotherapeutic agents on Broon-Pearce tumor and normal rabbit testis in vivo. Proc. Soc. Exper. Biol. \& Med., 84, 493-496.

Mantegazza, P., Mihich, E. and Tommasini, R. (1951): Attivita 'Di Alcuni Derivati Purinici Pirimidinici Sulla Crescifa, Nel Ratto, del Carcinoma di Walker 256. Boll Soc. Ital. Biol. Sper., 27, 1732-1735.

Skipper, H. E., Bennet, L. L., Edward, P. C., Bryan, C. E., Hutchison, O. S., Chapman, J. B. and Bell, M. (1950): Antileukemic assays on certain pyrimidines, purines, benzimidazole and related compounds. Cancer Res., 10, 166-169.

Sugiura, S. (1955): Studies in a spectrum of mouse and rat tumors. Cancer Res., Supplement, 3, 18-27.

Tamm, I., Folkers, K. and Horsfall, F. L. (1951): Inhibition of influenza virus multiplication by 2,5-dimethyl-benzimidazole. Yale J. Biol. \& Med., 24, 559-567.

Tamm, I., Folkers, K., Shunk, C. H., Heyl, D and Horsfall, F. L. (1953) : Inhibition of influenza virus multiplication by alkyl derivatives of benzimidazole. J. Exper. Med., 98, 245-259.

Tamm, I., Folkers, K., Shunk, C. H. and Horsfall, F. L. (1954): Inhibition of influenza virus multiplication by N-glucosides of benzimidazoles. J. Exper. Med., $99,227-250$.

Tamm, I., Folkers, K. and Shunk, C. H. (1956) : High inhibitory activity of certain halogenated ribofuranosyl benzimidazoles in influenza $B$ virus multiplication. J. Bact., 72, 54-58. 